\title{
Use of Integrated Mobile Application With Realistic Mathematics Education: A Study to Develop Elementary Students' Creative Thinking Ability
}

\author{
https://doi.org/10.3991/ijim.v13i10.11598 \\ Hendra Erik Rudyanto ${ }^{\bowtie}$, Anik Ghufron, Hartono \\ Universitas Negeri Yogyakarta, Indonesia \\ hendra.erik2016@student.uny.ac.id
}

\begin{abstract}
One of the abilities students must possess is Creative Thinking Ability (CTA) in order to succeed in their lives. Learning must facilitate students to develop CTA; one of them is by developing a mobile application based on Realistic Mathematics Education (RME). The purpose of this study is to determine the level of validity/feasibility, practicality, and effectiveness of mobile application based RME. This mobile application development used the ADDIE model development procedure. The subjects in this study were grade 4 elementary school students. The validation data collection techniques through validation sheets, practicality data through CTA tests. The results of the study show that the developed of mobile application integrated with realistic mathematics meets valid/proper requirements based on expert and practitioner assessments that are practical and easy if applied in mathematics learning and that is effective in improving students' creative thinking ability.
\end{abstract}

Keywords - mobile application, realistic mathematics, creative thinking ability

\section{Introduction}

Every individual need to master the Creative Thinking Ability (CTA) in facing the demands of the 21st-century. Considering the high level of complexity of life's problems, it is essential that CTA is mastered high [1], [2]. Even Mahmudi revealed that the world of work requires individuals who have a high CTA [3]. Only individuals who have a CTA can succeed, given the rapid global development over time.

Innovation technologies in education learning can have a potential impact or effect on the quality of process education learning [4]-[6]. Innovation and learning which includes collaboration, creativity skills, communication, and critical thinking are the 21st-century competency framework that used to called as (4CS) [2], where CTA is included. CTA, including High Order Thinking (HOT) or in other terms, is a high-level thinking ability. Anderson \& Krathwohl in Bloom's taxonomic revision, the ability to create is the highest aspect or level of thinking [7]. Then HOT is a relevant competence in solving problems and facing global life in the 21 -st century [8]-[10] because in principle HOT plays a fundamental role in connecting and implementing aspects of 
knowledge to solve problems effectively and efficiently [11]. To equip each individual in mastering CTA, various efforts must be made as early as possible, including for elementary school students, which elementary school students are at the level of laying the foundation of various knowledge and skills. Therefore, the broadest opportunities must be given to students so that CTA can be facilitated and developed, one of which is in learning mathematics.

Mathematics is essential to be mastered by students so that students have fundamental abilities including analytical, critical, creative, and logical thinking [12]. In order for CTA to be facilitated in schools, mathematics learning must make a useful contribution to the CTA development effort [13]. The role of educators or in this case, the teacher is very fundamental in order to build a learning atmosphere that creates spaces to improve and develop these competencies. So, innovation must be done continuously so that students are honed and grow their CTA.

In order for students to love mathematics and CTA can develop, innovation in learning mathematics must always be done by the teacher [14]. So, developing a mobile application is one alternative solution that can be done so that students are enthusiastic in learning mathematics. Because, in principle, mobile learning can facilitate the characteristics of students at the elementary school level, which according to Piaget is included in the concrete operational stage [15]. Mobile learning offers one of the easiest and fastest ways to bring education to the students [16]. Of course, the mobile application must be able to facilitate the CTA of these students.

One approach to learning mathematics that is suitable to be applied in elementary schools is realistic mathematics learning or known as Realistic Mathematics Education (RME), which was developed in the 1970s by Hans Freudenthal in the Netherlands. Mathematics is that human activity is the central concept carried in the learning of RME [17], [18]. RME helps bridge mathematical concepts with real-life situations.

Referring to the problems mentioned above, alternative solutions are needed in order to improve CTA in primary schools. Alternative problem solving should be adjusted to the characteristics of elementary school students, namely by developing a mobile application based on RME learning. This is relevant to the entry of the era of the industrial revolution 4.0 in this world considering the need for information technology (IT) which is now a necessity of human life [19].

\section{Methods}

Two methods used in this study include development research [20], [21] to develop mobile application integrated with RME and experimental methods using post-test only control group design [22] used to measure the effectiveness of mobile application developed on CTA of elementary school students. The ADDIE development model is used as a development procedure which includes the problem analysis stage, media prototype design, media development, implementation, and evaluation.

The sample of this study were 64 elementary school students in Bantul district, Yogyakarta, which were divided into 32 experimental class students (class A) and 32 students as control class (class B) in the 2018/2019 school year. Posttest Only Control 
Group is a design used by giving posttest at the end of learning in the experimental and control class. The experimental class was given treatment using a mobile application based on RME learning and control class without using media. The average posttest results in the two groups were then analyzed.

The instrument to measure the validity of the product in the form of a validation sheet assessed by practitioners and experts consisting of 3 experts and 2 practitioners. The instrument used in the practical aspect was in the form of a student response questionnaire to find out the students' responses to the developed media, as well as an observation sheet of student activities in learning with the mobile application. The aspect of mobile application effectiveness the instrument was used in the form of a test of creative thinking skills that had been tested and declared valid and reliable based on empirical tests.

The primary data of this study are quantitative data consisting of the results of expert and practitioner validator assessments, student response data, assessment at the time of observation (student activities in participating in learning), and the value of students' creative thinking abilities (CTA). The effectiveness of the mobile application based on RME was analyzed using the t-test formula [22].

\section{Results and Discussion}

The first principle in realistic learning, learning begins with contextual problems (use a context) related to everyday life. Activities carried out by observing objects around students through observing the object directly or through pictures. For example, observing objects in the form of objects that resemble the wake of space or a flat wake. Students can observe the object or model directly to identify the characteristics of the observed structure, so students can discover the characteristics of the shape through the models that he developed himself (use models) and it is on this principle that CTA is developed. In RME learning, the interaction between students and teachers (student contribution and interaction) is possible, both through presentations and group discussions. All components are integrated into the developed mobile application. Then students can associate (intertwining) mathematical concepts that they learn with problems in everyday life. Explicitly the mobile application footage developed is as shown in Figures 1 and 2 .

The recapitulation of mobile application based on RME learning assessment by experts and practitioners states that the developed mobile is very feasible/valid. The results of the criteria obtained refer to the indicators of eligibility/validity determined by the previous researcher. The results of the evaluation of the five validators consisting of 3 experts, 2 practitioners were averaged, and their eligibility criteria concluded. Table 1 shows the recapitulation of the results of the five validators' assessments. 


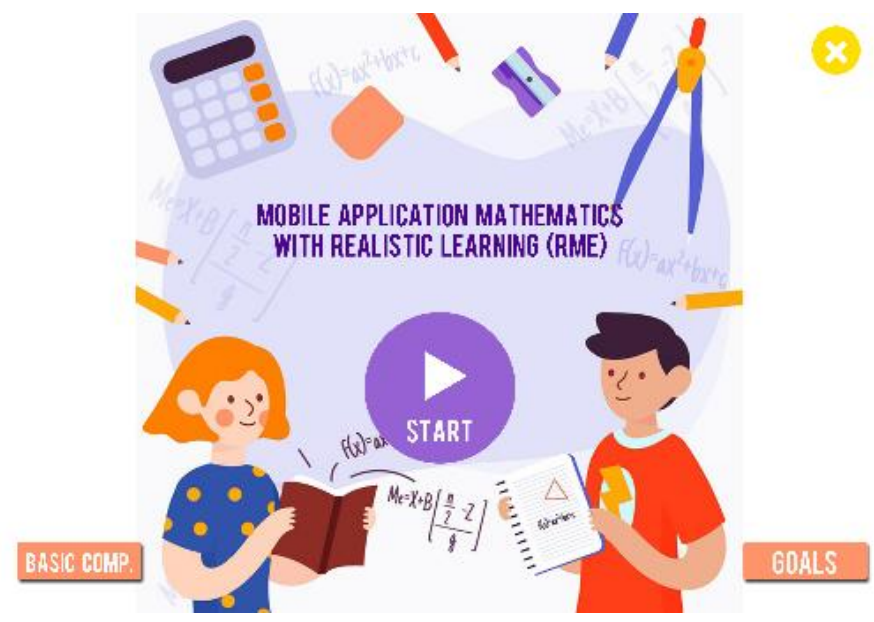

Fig. 1. Cover of a mobile application with RME

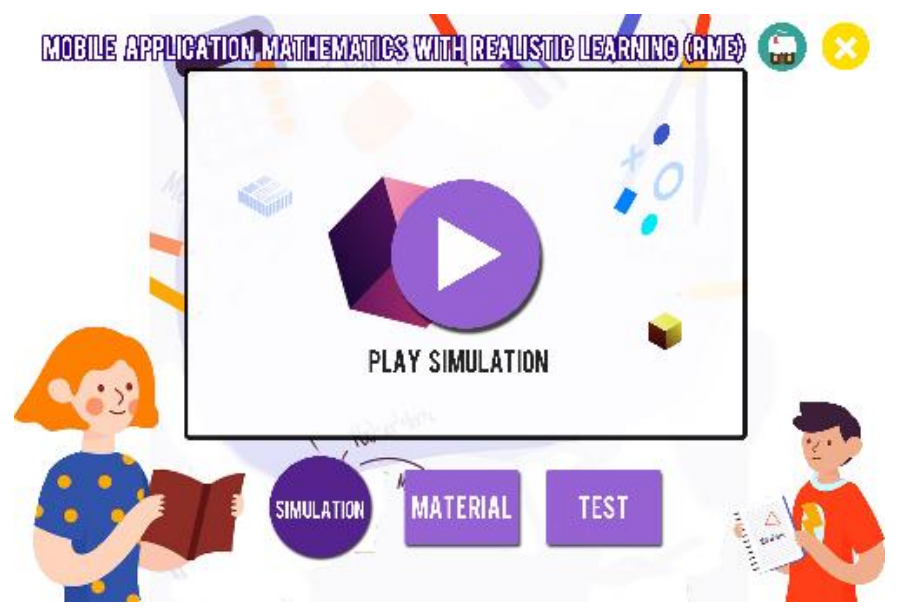

Fig. 2. Realistic Learning Material

Table 1. Results of validity the mobile application

\begin{tabular}{lccccc}
\hline \multirow{2}{*}{ Aspect } & \multicolumn{5}{c}{ Validator } \\
\cline { 2 - 6 } & $\mathbf{1}$ & $\mathbf{2}$ & $\mathbf{3}$ & $\mathbf{4}$ & $\mathbf{5}$ \\
\hline Format & 3.3 & 3.4 & 3.6 & 3.2 & 3.5 \\
Content & 3.3 & 3.4 & 3.4 & 3.2 & 3.5 \\
Language & 3.5 & 3.5 & 3.2 & 3.5 & 3.4 \\
Mean & 3.4 & 3.4 & 3.4 & 3.3 & 3.5 \\
Total & \multicolumn{5}{c}{ very valid } \\
Criteria & \multicolumn{7}{c}{3.4} \\
\hline
\end{tabular}


The validator assessed that the mobile application based on RME learning developed by 5 people consisted of 3 experts from academics in each field and 2 practitioners from elementary schools. The average rating of validator I is 3.3 , validator II is 3.4 validator III is 3.4 , validator IV is 3.3 , and validator $\mathrm{V}$ is 3.5 . The average number of evaluations for the five validators is 3.4 , which means it is very feasible / very valid. So based on the recapitulation results it can be concluded that mobile application based on RME is very valid or very feasible to use in learning mathematics in elementary schools.

In the practical aspects of mobile application based on RME developed in this study were measured through student responses and student activities when participating in learning. The mobile application is said to be practical if student responses are positive and student activity is high

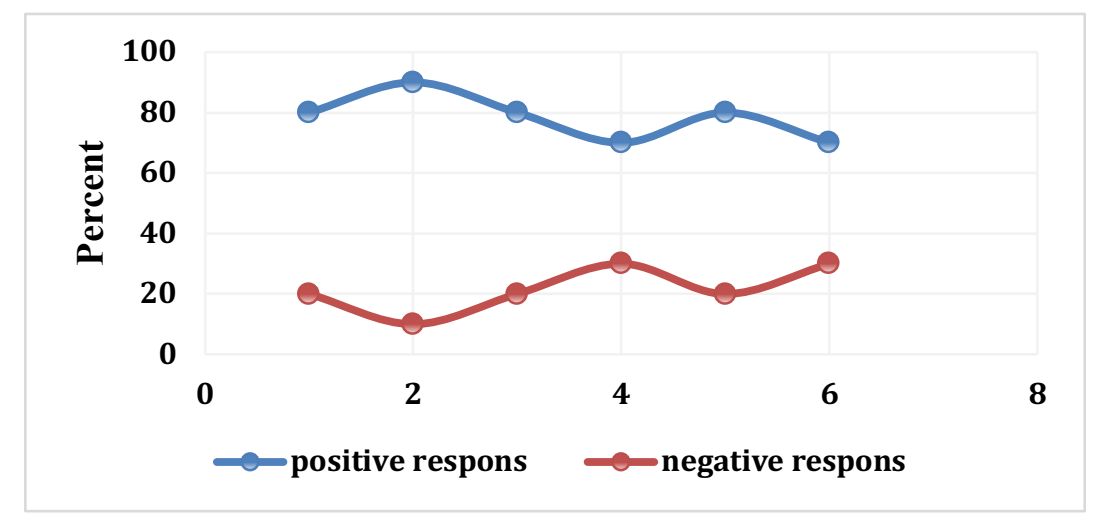

Fig. 3. Students respond

The graph above shows the percentage of students' response data on the 6 aspects measured. Where in the first aspect as much as $80 \%$ of students gave positive responses and $20 \%$ positive responses. In the second aspect, $90 \%$ gave positive responses, and $10 \%$ negative responses. In the third aspect, $80 \%$ of students gave positive responses, and $20 \%$ gave negative responses. The fourth aspect as much as $70 \%$ of students gave positive responses, and 30\% responded negatively. The fifth meeting as much as $80 \%$ gave a positive response and $20 \%$ gave a negative response. Moreover, in the sixth aspect, as many as $70 \%$ of students gave positive responses, and $30 \%$ of students gave negative responses. Overall, students gave a very positive response to the media developed.

Learning in each meeting measured student involvement/student activity. Observer observes student activities from the beginning of learning until the end of learning. Student activities displayed during the 6 meetings were observed by observers at each meeting. Following are the observations made at six meetings on mathematics learning.

The validator assessed that the media developed by 5 people consisted of 3 experts from academics in each field and 2 practitioners from elementary schools. The average rating of validator I is 3.3, validator II is 3.4 validator III is 3.4, validator IV is 3.3, and validator $\mathrm{V}$ is 3.5 . The average number of evaluations for the five validators is 3.4 , which means it is very feasible / very valid. So based on the recapitulation results it can 
be concluded that mobile application based on RME is very valid or very feasible to use in learning mathematics in elementary schools.

In the practical aspects of a mobile application developed in this study were measured through student responses and student activities when participating in learning. The mobile application is said to be practical if student responses are positive and student activity is high.

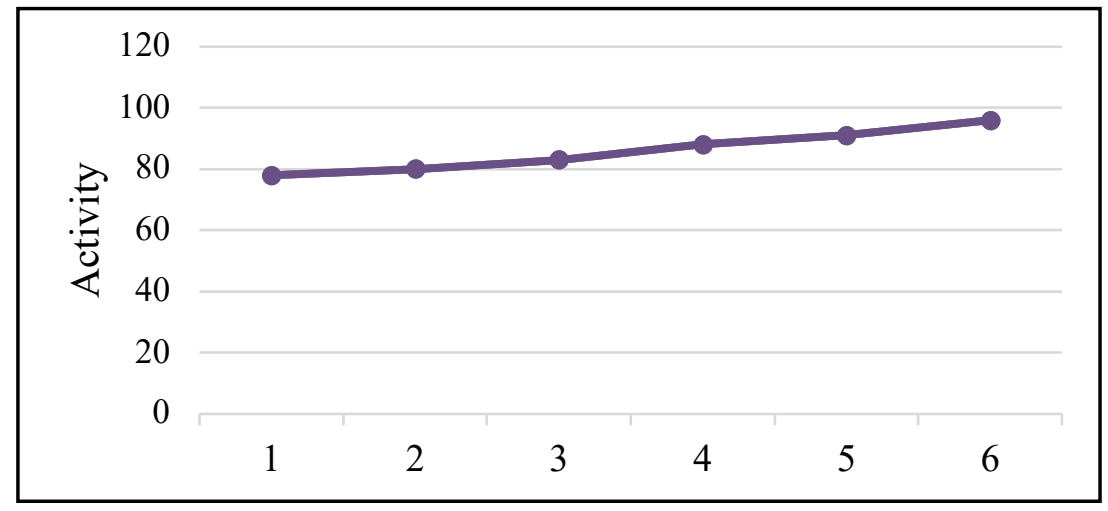

Fig. 4. Graphics of students activity

At each meeting, the activity of students experienced a significant increase. This means that the activities of students in participating in learning mathematics with the mobile application based on RME developed have increased and active students. The mobile application is a technology that can be of use within education [16] and can increase their creative thinking skills [23].

Flexibility, fluency, originality, and elaboration [24] are the four aspects of CTA measured in this study. Flexibility is the number of ways students use to solve mathematical problems, fluency is the number of answers put forward by students, elaboration is the detail of students in describing the details of answers, and originality is ideas that are raised by students. Indicators to see whether the mobile application based on RME developed is effective in improving students' thinking skills (CTA), so an experiment is needed to compare the average class that applies media with the t-test. Comparison of the value of the experimental class and the control class can be seen in Figure 5 .

Based on the data analysis, the value of $t$-count $=3.867$ with $t$-table $=1.670$ with $\alpha$ $=5 \%$, so $\mathrm{t}$-count $>\mathrm{t}$-table. The mean value of the experimental class was 81.25 , and the average value of the control class was 71.59. Based on these calculations, it can be concluded that the average experimental class implementing a mobile application based on RME is better than the average control class. High order competencies must be achieved through mathematics learning as a continuation of achieving students' basic skills by developing CTA. This challenge must be used as a guideline in learning mathematics so that teachers continue to be motivated in building students' experiences in learning mathematics. This condition is very relevant considering life problems that are very complex and not simple. 


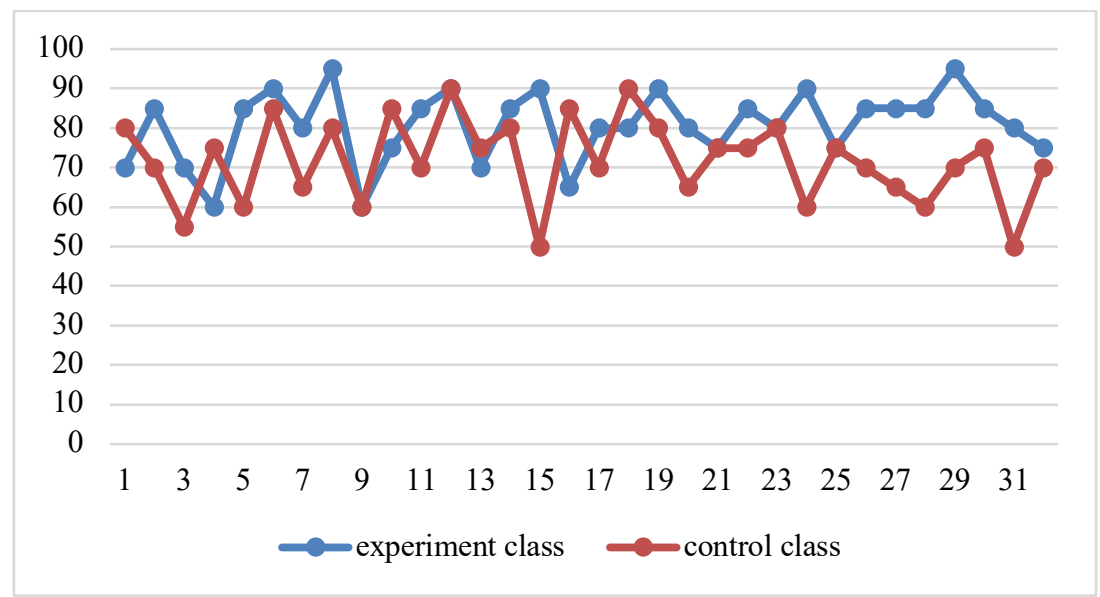

Fig. 5. Results of experimental class and control class

This developed application based on RME learning can develop the creative thinking skills of elementary school students. These conditions are in line with the students' goal in learning mathematics so that students can solve problems in life [14]. Also, CTA equips students to face the challenges of the workforce [3], [25]. However, in schools pay less attention to aspects of CTA and ultimately this ability does not develop [26]. Of course there are many aspects that can affect the maximum CTA of students. Even Marpaung states that learning that runs today still uses the teaching paradigm [27].

Consequently, students are not allowed to express themselves in learning mathematics so that students are passive in learning. In other words, mathematics learning is conventional or the teacher dominates in learning [28] because learning is routine. Through mobile application based on realistic mathematics that is developed can have a positive impact, especially in the development of student creative thinking student.

\section{Conclusion}

The mobile application based on realistic mathematics meets valid or appropriate criteria based on the judgment of practitioners and experts. This mobile application also meets practical criteria when applied in mathematics learning. This can be seen from the positive student responses to the developed mobile application and high student activities when participating in learning with the developed mobile application. Besides that the mobile application integrated with realistic mathematics is effective in developing creative thinking. Innovations in learning mathematics like this must always be actively done by the teacher so that students master mathematical abilities that can later be useful in solving problems in their lives. Therefore, a mobile application integrated with realistic mathematics must always facilitate the development and improvement of creative thinking students in primary education. 


\section{$5 \quad$ References}

[1] E. M. Mursidik, N. Samsiyah, and H. E. Rudyanto, "Kemampuan Berpikir Kreatif Dalam Memecahkan Masalah Matematika Open-Ended Ditinjau Dari Tingkat Kemampuan Matematika Pada Siswa Sekolah Dasar,” J. Pedagog., vol. 4, no. 1, pp. 23-33, 2015. https://doi.org/10.21070/pedagogia.v4i1.69

[2] H. Retnawati, H. Djidu, Kartianom, E. Apino, and R. D. Anazifa, "Teachers’ Knowledge About Higher-Order Thinking Skills And Its Learning Strategy," Probl. Educ. 21st Century, vol. 76, no. 2, pp. 215-230, 2018. https://doi.org/10.1201/9781315104188-32

[3] A. Mahmudi, "Mengukur Kemampuan Berpikir Kreatif Matematis," in Makalah. Konferensi Nasional Matematika XV UNIMA, 2010.

[4] M. F. Amir, N. Fediyanto, C. Chotimah, and H. E. Rudyanto, "Developing 3Dmetric Media Prototype through a Hypothetical Learning Trajector to Train Students Spatial Skill," J. od Adv Res. Dyn. Control Syst., vol. 10, no. 02 Special Issue, pp. 1537-1542, 2018. https://doi.org/10.31227/osf.io/vmk45

[5] M. F. Amir, C. Chotimah, R. Afandi, H. E. Rudyanto, and I. Anshori, "Design Research Study : Investigation of Increasing Elementary Student' s Spatial Ability Using 3Dmetric," J. Adv. Res. Dyn. Control Syst., vol. 10, no. 6, pp. 1707-1713, 2018. https://doi.org/10.31 227/osf.io/6fbzj

[6] H. Saleh, Nurdyansyah, F. N. Hasanah, H. E. Rudyanto, and Mu'alimin, "Application of classroom response systems (CRS): study to measure students learning outcome," Int. J. Emerg. Technol. Learn., vol. 14, no. 14, pp. 132-142, 2019. https://doi.org/10.3991/ ijet.v14i14.10506

[7] O. W. Anderson and D. R. Krathwohl, A taxonomy for learning, teaching, and assessing: A revision of Bloom's taxonomy of educational objectives. New York: Longman, 2001.

[8] S. M. Brookhart, How to assess higher-order thinking skills in your classroom. Alexandria: ASCD, 2010.

[9] D. Moseley et al., Frameworks for thinking: A handbook for teaching and learning. New York: Cambridge University Press, 2005.

[10] T. Thompson, "Mathematics teachers' interpretation of higher-order thinking in Bloom's taxonomy," Int. Electron. J. Math. Educ., vol. 3, no. 1, pp. 1-14, 2008.

[11] A. Thomas and G. Thorne, "How to increase higher order thinking," http://www.readingrockets.org/article/how-increase-higher-order-thinking, 2009. .

[12] Depdiknas, "Peraturan Menteri Pendidikan Nasional Republik Indonesia 22 Tahun 2006 tentang Standar Isi untuk Satuan Pendidikan Dasar dan Menengah," 2006. https://doi.org/10.14421/al-bidayah.v10i2.167

[13] H. E. Rudyanto, "Pengembangan Kreativitas Siswa Sekolah Dasar Melalui Pembelajaran Matematika Open-Ended,” J. Prem. Educ., 2013. https://doi.org/10.25273/pe.v3i02.275

[14] V. Švecová, L. Rumanová, and G. Pavlovičová, "Support of Pupil's Creative Thinking in Mathematical Education," in 5th World Conference on Educational Sciences - WCES 2013, Procedia Sosial and Behavior Social Science, 2014, pp. 1715-1719. https://doi.org/10.1016/j.sbspro.2014.01.461

[15] J. W. Santrock, Educational psychology, Fifth. New York: The McGraw-Hill Companies, Inc., 2011.

[16] A. S. Drigas and P. Angelidakis, "Mobile Applications within Education An Overview of Application Paradigms in Specific Categories," Int. J. Interact. Mob. Technol., vol. 11, no. 4, pp. 17-29, 2017. https://doi.org/10.3991/ijim.v11i4.6589 
[17] N. O. Shanty, “Investigating Students' Development of Learn ing Integer Concept and Integer Addition," J. Math. Educ., vol. 7, no. 2, pp. 57-72, 2016. https://doi.org/10.22342/ jme.7.2.3538.57-72

[18] R. C. I. Prahmana, Zulkardi, and Y. Hartono, "Learning multiplication using Indonesian traditional game in third grade," J. Math. Educ., vol. 3, no. 2, pp. 115-132, 2012. https://doi.org/10.22342/jme.3.2.1931.115-132

[19] K. Schwab, The Fourth Industrial Revolution. Switzerland: Penguin, 2016.

[20] J. van den Akker, "Principles and Methods of Development Research," in Design approaches and tools in education and training, 1999, pp. 1-14. https://doi.org/10.1007/ 978-94-011-4255-7 1

[21] A. Rachmadany et al., "Classification of Indonesian quote on Twitter using Naïve Bayes," IOP Conf. Ser. Mater. Sci. Eng., vol. 2881, no. 1, p. 12162, 2018. https://doi.org/10.1088/ $1757-899 \mathrm{x} / 288 / 1 / 012162$

[22] Sugiyono, Metode penelitian kuantitatif, kualitatif dan R\&D. Bandung: Alfabeta, 2013.

[23] H. E. Rudyanto, A. Ghufron, Hartono, and S. Gembong, "Multimedia flash mathematics with cultural perspective (ethnomathematics) to develop elementary school students' creative thinking," J. Adv. Res. Dyn. Control Syst., vol. 6, no. Special Issue, pp. 1714-1720, 2018.

[24] N. M. Anwar, M. Aness, A. Khizar, M. Naseer, and G. Muhammad, "Relationship of Creative Thinking with Academc Achievements of secondary School Students," Int. Interdiciplinary J. Educ., vol. 1, no. 3, pp. 44-47, 2012.

[25] P. M. Kind and V. Kind, Creativity in Science Education: Perspectives and Challenges for Developing School Science. 2007.

[26] R. D. Anazifa and Djikri, "Project- Based Learning And Problem- Based Learning: Are They Effective To Improve Student's Thinking Skills?," J. Pendidik. IPA Indones., vol. 6, no. 2, pp. 346-355, 2017. https://doi.org/10.15294/jpii.v6i2.11100

[27] Y. Marpaung, "Perubahan Paradigma Pembelajaran Matematika di Sekolah," in Semnas Pendidikan Matematika di Universitas Sanata Darma, 2003.

[28] K. Gravemeijer and M. Doorman, "Context problems in realistics mathematics education: A calculus course as an example," Educ. Stud. Math., vol. 39, no. 1-3, pp. 111-129, 1999.

\section{$6 \quad$ Authors}

Hendra Erik Rudyanto is a doctoral student in Primary Education at Graduate School, Universitas Negeri Yogyakarta, Indonesia. He is a lecturer in elementary school teacher education department at Universitas PGRI Madiun, Indonesia.

Anik Ghufron is a lecturer in Primary Education at Graduate School, Universitas Negeri Yogyakarta, Indonesia.

Hartono is a lecturer in Mathematics Education at Graduate School, Universitas Negeri Yogyakarta, Indonesia.

Article submitted 2019-08-30. Resubmitted 2019-09-28. Final acceptance 2019-09-29. Final version published as submitted by the authors. 